\title{
ГОСТРІ ПОРУШЕННЯ МОЗКОВОГО КРОВООБІГУ У ХВОРИХ НА COVID-19
}

\author{
๑Т. М. Муратова', Д. М. Храмцов 1,3, Ю. М. Ворохта ${ }^{2,3}$, М. С. Вікаренко ${ }^{1,3}$, І. В. Добуш ${ }^{1,3}$, \\ Г. Г. Козлова ${ }^{1,3}$, Є. О. Андрющенко ${ }^{3}$, В. М. Сазонов ${ }^{3}$, В. А. Фащенко 3 \\ 1 Одеський національний медичний університет \\ ${ }^{2}$ Одеський міжнародний медичний університет \\ ${ }^{3}$ Приватний медичний центр "Expert Health", м. Oдеса
}

РЕЗЮМЕ. У грудні 2019 року з міста Ухань (провінція Хубей, Китай) надійшли перші повідомлення про COVID-19 - захворювання, спричинене новим тяжким гострим респіраторним синдромом коронавірусної етіології (SARS-CoV-2). 3 цього часу ця хвороба стала світовою пандемією. На сьогоднішній день загинуло понад 2,8 мільйона осі6 (BOO3, 2021). Вірус SARS-CoV-2 став сьомим відомим варіантом коронавірусу, патогенним для людини.

Метою огляду була оцінка впливу інфекції SARS-CoV-2 на поширеність ГПМК у країнах світу.

Матеріал і методи. Ретроспективне дослідження проведене за матеріалами міжнародних баз даних (CDC, BOO3), а також реєстрів ГПMK (SITS, resQ, DAP, GSR, SSR, LASE). Проведене зіставлення інкременту захворюваності на SARS-CoV-2 та ГПМК у динаміці з моменту виявлення перших випадків COVID-19. Статистичну обробку проводили за допомогою програмного забезпечення Statistica 13.0 (TIBCO Inc., США).

Результати. Частота ГПМК у світі корелює з поширеністю SARS-CoV-2. На ранніх стадіях пандемії COVID-19 відбувалося меншення захворюваності на ГПМК у розвинутих країнах. Існуючі міжнародні реєстри ГПМК відображають збереження цієї тенденції.

Висновки. 1. Пандемія COVID-19 пов'язана із глобальним зменшенням звернення за спеціалізованою медичною допомогою при ГПМК, що впливає на загальну кількість госпіталізацій та число процедур механічної тромбектомії. 2. Незважаючи на географічні розбіжності, це зменшення обсягу спостерігалося незалежно від тягаря госпіталізації COVID-19 та обсягів госпіталізації хворих з ГПМК у допандемічний період.

КлючОВІ СлОВА: гостре порушення мозкового кровообігу; коронавірусна інфекція; епідеміологія.

Вступ. У грудні 2019 року з міста Ухань (провінція Хубей, Китай) надійшли перші повідомлення про COVID-19 - захворювання, спричинене новим тяжким гострим респіраторним синдромом коронавірусної етіології (SARS-CoV-2) [1-3]. 3 того часу ця хвороба стала світовою пандемією, на сьогоднішній день загинуло понад 2,8 мільйона осіб (BOO3, 2021) [3]. Вiрус SARS-CoV-2 став сьомим відомим варіантом коронавірусу, патогенним для людини. SARS-CoV-2 генетично схожий на SARSCoV-1 (Wu et al., 2020) [2], який у 2003 р. уразив близько 8000 пацієнтів, у частини з яких виникали неврологічні прояви - переважно периферична нейропатія та енцефаліт (Tsai et al., 2005) [4]. Поді6но до SARS-CoV-1, SARS-CoV-2 впливає на нервову систему приблизно у 36,7 \% пацієнтів [5-7]. Є повідомлення про те, що PHK SARS-CoV-2 за допомогою ПЛР виявлено у спинномозковій рідині.

Рецептори до ангіотензинперетворювального ферменту 2-го типу (АПФ) є основними вхідними точками для ГРВІ, викликаних коронавірусами (Hoffmann et al., 2020) [8]. Ці рецептори АПФ-2 присутні й у нервовій системі, але на сьогодні запропоновані альтернативні гіпотези, які пояснюють потрапляння SARS-CoV-2 у нервову систему, включаючи пряме ушкодження гематоенцефалічного бар'єру, гіпоксійну травму та пов'язані з імунітетом ушкодження (Steardo et al., 2020, Wu et al., 2020) [2, 9].
Симптоми інфекції SARS-CoV-2 варіюють від безсимптомної хвороби до загрозливого для життя гострого респіраторного дистрес-синдромy (ARDS), тяжкої пневмонії, гострої травми нирок (AKI), міокардиту, поліорганної недостатності (Huang et al., 2020, Inciardi et al., 2020) [10, 11]. Останні публікації містять звітну інформацію щодо численних випадків неврологічних ускладнень, включаючи порушення мозкового кровообігу в пацієнтів із тяжким перебігом SARS-CoV-2 (Mao et al., 2020) [12].

Пандемія COVID-19 суттєво вплинула на систему надання медичної допомоги при інсульті у світі. У хворих на COVID збільшується ризик гострих порушень мозкового кровообігу (ГПМК) за ішемічним типом, водночас пацієнти з ГПМК особливо вразливі у випадку інфікування коронавірусом $[5-7,13]$. з урахуванням того факту, що частина інсультних центрів упродовж пандемії була переорієнтована на прийом насамперед хворих на COVID, ризики несприятливих наслідків ГПМК значно збільшуються [13].

Avula A. et al. (2020) нещодавно описали декілька випадків ішемічного інсульту в пацієнтів із підтвердженою ПЛР інфекцією SARS-CoV-2 на ранніх стадіях захворювання [14]. Раніше Mao et al. (2020) визначили, що у 5,7 \% пацієнтів з тяжким перебігом коронавірусної інфекції може виникати ГПМК [12]. У дослідженні Li Y et al. (2020) пока- 
Огляди літератури, оригінальні дослідження, погляд на проблему, випадок з практики, короткі повідомлення

зано, що частота інсульту в пацієнтів із COVID-19 складає близько 5 \% із середнім віком 71,6 років (Li et al., 2020) [15]. У цих хворих нерідко були присутні різноманітні коморбідні стани, у тому числі артеріальна гіпертензія, діабет, ішемічна хвороба серця та попереднє порушення мозкового кровообігу $[15,16]$. Середній час початку інсульту після діагностики COVID-19 становив 12 днів. Підвищений рівень СРБ та D-димеру, що вказують на активне запалення та порушення згортання крові відповідно, можуть відігравати роль у патофізіології інсульту в умовах зараження інфекцією COVID-19 [15].

Патофізіологічні механізми, що стоять за цими порушеннями мозкового кровообігу, ще належить визначити. Відомо, що як бактеріальні, так і вірусні інфекції спричиняють інсульти, збільшуючи ризики виникнення кардіоемболічних, а також гемодинамічних подій (Grau et al., 1998) [17]. Недавнє дослідження, проведене у Нідерландах, продемонструвало, що у 31 \% тяжких хворих розвиваються тромботичні ускладнення (Klock et al., 2020) [18]. В іншому дослідженні на основі аналізу динаміки активованого часткового тромбопластинового часу та тромбоеластографічних досліджень у пацієнтів із COVID-19 було зроблено висновок, що у них наявна виражена гіперкоагуляція, яка передує або збігається з іншими маніфестаціями тяжкої хвороби (Tan et al., 2020) [19]. Наразі в літературі є декілька повідомлень про тромбоемболії легеневих артерій у хворих на COVID-19 (Danzi et al., 2020) [20]. Результати аутопсії померлих від COVID-19 були опубліковані лише у кількох роботах, але на тромботичну мікроангіопатію в багатьох органах, особливо в легенях та нирках, вказують усі дослідники (Fox et al., 2020, Barton et al., 2020, Yao et al., 2020) [2123]. Опираючись на ці дані ймовірним механізмом раннього порушення мозкового кровообігу можна вважати насамперед гіперкоагуляцію, що призводить до утворення макро-та мікротромбів у судинах. Інша патофізіологічна модель може бути безпосередньо пов'язана з розвитком інфекційного процесу або прогресуючою гіпоксією $[2,5-7,13]$. Наразі необхідно продовжити дослідження для всебічного розуміння причин виникнення неврологічної патології при COVID-19 та механізмів впливу коронавірусної інфекції на нервову систему.

Немає однозначних повідомлень про ризики виникнення фібриляції передсердь (ФП) при інфікуванні COVID-19 [13, 24, 25]. Цілком ймовірно, що ФП може бути спровокована інфекцією COVID-19 [24]. Чинниками ризику називають лихоманку, гіпоксію, симпатикотонію та підвищений адренергічний тонус. У пацієнтів із тяжкою пневмонією, гострою вірусною інфекцією та сепсисом частота ФП під час госпіталізації висока [24-27]. Так, 2333 \% тяжкохворих та хворих на сепсис або гострий респіраторний дистрес-синдром (ГРДС) мали рецидив ФП, а у $10 \%$ ФП дебютувала на фоні SARS [25]. ФП при сепсисі та ГРДС асоціювалась із вищою смертністю, у цих пацієнтів частіше реєструвалися випадки ГПМК. В недавньому італійському дослідженні серед 355 пацієнтів, які померли від COVID-19 (середній вік 79,5 років, 30 \% жінок), ретроспективний аналіз виявив ФП у 24,5\% пацієнтів [28]. Виникненню ФП сприяють гіпокаліємія та гіпомагнезіємія (викликана нудотою, анорексією, діареєю та прийомом медикаментів), метаболічний ацидоз, використання інотропних засобів (особливо добутаміну та дофаміну), дисинхронія апарату штучної вентиляції легень, перевантаження об'ємом, підвищення симпатичного тонусу, запалення, гіпоксія, ішемія, бактеріальна суперінфекція та травма міокарда [24, 25, 28].

Щодо тактики ведення хворих, які отримують антикоагулянтну або антитромбоцитарну терапію за показаннями, в тому числі у випадку виникнення ГПМК, то сучасні клінічні настанови рекомендують продовжувати прийом цих ліків навіть якщо у них діагностують діагноз COVID-19 (AIII) [29]. Iturbe-Hernandez T. et al. (2020) вважають найбезпечнішим призначення дабігатрану, з огляду на часті явища гепатотоксичності при лікуванні тяжкої COVID-19 пневмонії [30]. Однак у такої точки зору бракує доказовості - на сьогодні переваги жодного з НОАК при ФП на фоні COVID-19 не доведені.

У деяких клінічних настановах розглядається доцільність превентивного призначення НОАК у пацієнтів з COVID-19, але такі підходи виглядають недостатньо обґрунтованими [31-33].

Згідно з базою даних клінічних випробувань Центру розвідки фармацевтичних препаратів GlobalData, наприкінці 2020 року в США було проведено лише два клінічні випробування щодо використання нових пероральних антикоагулянтів (NOAC) у амбулаторних хворих на COVID-19 з метою запобігання розвитку тромбозів. Це дослідження III етапу PREVENT-HD компанії Johnson \& Johnson, яке оцінює, чи зменшує ривароксабан ризик тромботичних подій, госпіталізацію з усіх причин та смертність від усіх причин у амбулаторних хворих з гострою інфекцією COVID-19, а також дослідження фази III, що оцінює застосування апіксабану та аспірину (в окремих лікувальних групах) у дорослих з COVID-19, яким не потрібна госпіталізація на момент діагностики $[31,32]$. Втім, згідно з рекомендаціями Національного інституту охорони здоров'я, які були оновлені на початку поточного року, не госпіталізовані пацієнти з COVID-19, які пе- 
Огляди літератури, оригінальні дослідження, погляд на проблему, випадок з практики, короткі повідомлення

ребувають на амбулаторному лікуванні, не повинні отримувати профілактичні антикоагулянти та антиагрегантну терапію [33].

Європейське кардіологічне товариство нещодавно запропонувало алгоритм антикоагуляції для хворих на COVID-19 із високим тромботичним ризиком, які визначаються як такі, що мають задишку, частоту дихання більше 24, SpO $2<90 \%$, підвищений С-реактивний білок, підвищення рівня D-димеру та підвищений рівень фібриногену. Таким хворим в умовах інтенсивної терапії слід розпочинати парентеральний протокол крапельного введення гепарину з ретельним спостереженням та встановленням активного часу протромбопластину в межах 60-85 с. Для пацієнтів, які не перебувають у відділенні інтенсивної терапії, рекомендують використовувати підшкірний еноксапарин у дозі 1 мг/кг двічі на день або враховувати той самий протокол гепарину, який застосовують для пацієнтів інтенсивної терапії. Крім того, рекомендують використовувати ультразвукове дослідження при підозрі на тромбоз глибоких вен із продовженням терапевтичної антикоагуляції за умов позитивного результату. При відсутності ознак тромбозу рекомендується деескалація дози еноксапарину до 40 мг на добу [34]. За даними Tang D. et al., (2020) при необґрунтованому застосуванні гепаринотерапії зростає ризик ускладнень у вигляді компартизації патогену та подальших судинних подій [35]. Неприйнятним виглядає й застосування практики off-label призначень різноманітних противірусних, протималярійних, імуномодулювальних та антиагрегантних засобів [36-38].
Всесвітня організація боротьби з інсультом (WSO) проголошує надзвичайну важливість проблеми ГПМК під час пандемії COVID-19 у країнах, що розвиваються [39]. Для них характерний не лише низький рівень розвитку медицини невідкладних станів, а й загальний низький соціально-економічний рівень, що утруднює проведення карантинних заходів. Крім того, особливості етнічного складу також можуть впливати на сприйнятливість до інфекції та на тяжкість її клінічних проявів. Так, за даними літератури, перебіг захворювання $\epsilon$ тяжчим у представників негроїдної раси [1, 40]. Наявність генетичної схильності може обумовлювати й ризик виникнення ГПМК у хворих на COVID-19. Це обумовило запуск таких наукових проектів як COVID-19 Host Genetics [40, 41].

Метою огляду була оцінка впливу інфекції SARS-CoV-2 на поширеність ГПМК у країнах світу.

Матеріал і методи дослідження. Ретроспективне дослідження проведене за матеріалами міжнародних баз даних (CDC, BOO3), а також реєстрів ГПMК (SITS, resQ, DAP, GSR, SSR, LASE). Проведене зіставлення інкременту захворюваності на SARS-CoV-2 та ГПMК у динаміці з моменту виявлення перших випадків COVID-19. Статистичну обробку проводили за допомогою програмного забезпечення Statistica 13.0 (TIBCO Inc., США).

Результати й обговорення. Як показали результати аналізу, загалом у країнах з високим ступенем епідеміологічної небезпеки є тенденція до зростання кількості ГПМК за ішемічним типом (рис. 1).

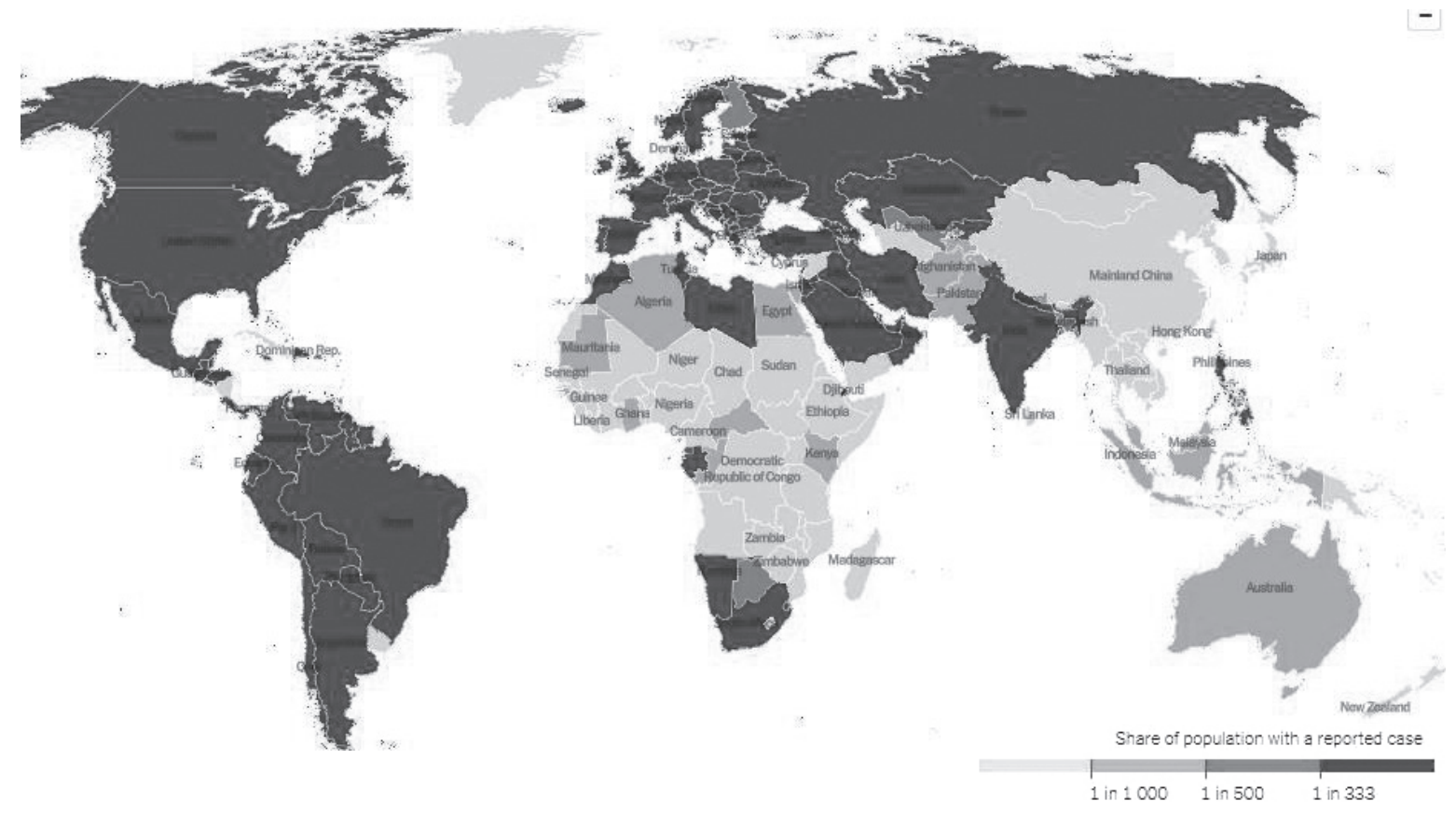

Рис. 1. Поширення SARS-CoV-2 та гострого порушення мозкового кровообігу в світі [1]. 
Огляди літератури, оригінальні дослідження, погляд на проблему, випадок з практики, короткі повідомлення

На жаль, наявні на сьогодні записи реєстрів ГПМК є неповними, тому основні зіставлення були проведені лише за даними кінця 2019 - початку 2020 року, тобто періоду, який відповідає «першій хвилі» пандемії $[1,2] .3$ іншого боку, останнім чаcoм накопичені дані щодо впливу SARS-CoV-2 на реєстрацію ГПМК відповідно до процедури «інсультний код" (пренотифікація при надходженні). У роботі Shatzkes D. R. et al., (2021) не знайдено статистично значущих відмінностей у демографічних та клінічних характеристиках та у даних позитивних показників при порівнянні періодів на початку епідемії та наприкінці 2020 року [42].

Вісімдесят три відсотки (620/750) кодів інсульту були названі у відділенні невідкладної допомоги, решта 17 \% (130/750) - в інших стаціонарних відділеннях. 3 плином епідемії COVID-19 число госпіталізацій з ГПМК значуще зросло ( $p=0.0335)$. Водночас збільшилася частка пацієнтів з тяжчими інсультами за оцінкою NIHSS. На початку 2020 року 27 \% пацієнтів з ГПМК на момент надходження у стаціонар були COVID-19позитивними, але у 45 \% серологічний статус наразі був невідомий [42].

Низка авторів підтверджують попередні повідомлення про зменшення захворюваності на ГПМК на ранніх стадіях пандемії COVID-19 [43-45]. Kansagra et al. (2020) повідомили про зниження використання програмного забезпечення RAPID на 39 \% із визначеного передпандемічного періоду з 1 лютого по 29 лютого 2020 року, порівняно з пандемічним періодом з 26 березня по 8 квітня 2020 року [43], a de Havenon показали зниження числа госпіталізацій з діагнозом ГПМК приблизно на $18 \%$ [44]. Проаналізувавши дані національного репозиторію електронних медичних записів від відвідувань закладів у справах ветеранів, Ваum et al. (2020) виявили зменшення загального прийому на 41,9\%, а пацієнтів, які поступили з основним діагнозом інсульт, - на 51,9 \% [45]. Цілком ймовірно, що це падіння має багатофакторне походження, хоча здається ймовірним, що небажання пацієнтів звертатися за медичною допомогою умовах епідемії мало головне значення. Загальнонаціональне обстеження відвідувань відділень невідкладної допомоги, проведене CDC, показало падіння звернень за інсультною допомогою на 42 \% за період пандемії. У загальнонаціональному опитуванні, в якому взяли участь більше 1000 респондентів, проведеному Товариством серцево-судинної ангіографії та втручань, 61 \% респондентів вважали, що, ймовірно, інфікувалися COVID-19 у лікарні, а половина з них більше боялася заразитися цим захворюванням, аніж захворіти на інфаркт або інсульт. Зменшення доступності медичних ресурсів, включаючи швидку допомогу, також сприя- ло зменшенню кількості звернень у профільні відділення. Крім того, можливо, що на ранній фазі пандемії багато фахівців у відділеннях невідкладної допомоги, переповнених пацієнтами з COVID-19, рідше активували інсультний код. Рекомендації щодо «захищеного» лікування гіпергострого інсульту з використанням засобів індивідуального захисту та інших заходів безпеки з'явилися пізніше, під час пандемії, і страх перед внутрішньолікарняною інфекцією, можливо, так само вплинув на тактику для ініціювання коду інсульту.

Цікаву інформацію наводять Greenwood J. et al. (2021). За їх даними, під час епідемії звернення до стаціонарів з ГПМК зменшилося на 40 \%, причому також збільшилася затримка у наданні реваскуляризуючих медичних втручань [46]. Крім того, значно зросла частота госпіталізації пацієнтів із невідомим часом початку інсульту.

За даними Mendes A. et al. (2021) інсульти у хворих на COVID-19 частіше реєструються у пацієнтів похилого віку [47]. Для цієї вікової групи характерні часті делірійні прояви та зниження рівня свідомості, причому найчастіше страждає басейн СМА. 3 іншого боку, перебіг ГПМК у паці$\epsilon$ нтів похилого віку не впливав ані на рівень ранньої смертності, ані на терміни виписування з лікарні [48].

Люди, які пережили COVID-19, як з проявами гострих судинних ускладнень, так і без них, можуть мати більший ризик розвитку ФП у майбутньому, що збільшує ризик кардіоемболічного інсульту [24-27]. Обговорюється також потенційне зростання поширення частоти криптогенних ГПМК за ішемічним типом $[13,24]$. На жаль, досі бракує даних із реєстрів COVID-19, довгострокових спостережень за реконвалесцентами після COVID-19, та досліджень, що порівнюють частоту цереброваскулярної патології у пацієнтів з COVID-19 [49].

За даними французського національного реєстру, серед 55309 пацієнтів, госпіталізованих з приводу інсульту, лише 520 (0,9%) мали супутній діагноз COVID-19 або таку діагностику до індексу госпіталізації з приводу інсульту [50]. Пацієнти 3 COVID-19 мали більше супутніх захворювань, більшу поширеність серцевої недостатності, аритмій та венозної тромбоемболії, порівняно з ковід-негативними пацієнтами. Пацієнти з ГПМК із діагностованою гострою коронавірусною інфекцією COVID-19 частіше помирали в лікарні, аніж реконвалесценти з постковідними інсультами.

В Ізраїлі під час епідемії значно зменшилося число госпіталізацій хворих з приводу ТІА (на 47,6 \%) та ГПМК (на 29,3 \%) [51]. Подібні дані одержані й в інших регіонах світу $[52,53]$.

Висновки. 1. Пандемія COVID-19 пов'язана із глобальним зменшенням звернення за спеціалі- 
Огляди літератури, оригінальні дослідження, погляд на проблему, випадок з практики, короткі повідомлення

зованою медичною допомогою при ГПМК, що впливає на загальну кількість госпіталізацій та число процедур механічної тромбектомії.

2. Незважаючи на географічні розбіжності, це зменшення обсягу спостерігалося незалежно від тягаря госпіталізації COVID-19 та обсягів госпіталізації хворих із ГПМК у допандемічний період.

Перспективи подальших досліджень можуть бути пов'язані із аналізом епідеміології ГПМК на фоні епідемії COVID-19 в Україні.

\section{ЛІТЕРАТУРА}

1. Evolutionary history, potential intermediate animal host, and cross-species analyses of SARS-CoV-2 / X. Li, J. Zai, Q. Zhao [et al.] // J. Med. Virol. - 2020. - Vol. 92 (6). P. 602-611.

2. Genome Composition and Divergence of the Novel Coronavirus (2019-nCoV) Originating in China / A. Wu, Y. Peng, B. Huang [et al.] // Cell Host Microbe. - 2020. Vol. 27 (3). - P. 325-328.

3. COVID-19 coronavirus pandemic. [Електронний ресурс]. - Режим доступу: https://www.worldometers. info/coronavirus.

4. Tsai L. K. Neurological manifestations in severe acute respiratory syndrome / L. K. Tsai, S. T. Hsieh, Y. C. Chang // Acta Neurol. Taiwan. - 2005. - Vol. 14 (3). - P. 113-119.

5. A first case of meningitis/encephalitis associated with SARS-Coronavirus-2 / T. Moriguchi, N. Harii, J. Goto [et al.] // Int. J. Infect. Dis. - 2020. - Vol. 94. - P. 55-58.

6. Nervous system involvement after infection with COVID-19 and other coronaviruses / Y. Wu, X. Xu, Z. Chen [et al.] // Brain Behav. Immun. - 2020. - Vol. 87. - P. 18-22.

7. Hess D. C. COVID-19-Related Stroke / D. C. Hess, W. Eldahshan, E. Rutkowski // Transl. Stroke Res. - 2020. Vol. 11 (3). - P. 322-325.

8. SARS-CoV-2 cell entry depends on ACE2 and TMPRSS2 and is blocked by a clinically proven protease inhibitor / M. Hoffmann, H. Kleine-Weber, S. Schroeder [et al.] // Cell. - 2020. - Vol. 181 (2). - P. 271-280.

9. Neuroinfection may contribute to pathophysiology and clinical manifestations of COVID-19 / L. Steardo, L. Steardo Jr, R. Zorec, A. Verkhratsky // Acta Physiol. (Oxf). - 2020. - Vol. 229 (3). - e13473.

10. Clinical features of patients infected with 2019 novel coronavirus in Wuhan, China / C. Huang, Y. Wang, X. Li [et al.] // Lancet. - 2020. - Vol. 395 (10223). - P. 497-506.

11. Cardiac involvement in a patient with coronavirus disease 2019 (COVID-19) / R. M. Inciardi, L. Lupi, G. Zaccone [et al.] // JAMA Cardiol. - 2020. - Vol. 5 (7). - P. 819-824.

12. Neurologic manifestations of hospitalized patients with coronavirus disease 2019 in wuhan, china / L. Mao, H. Jin, M. Wang [et al.] // JAMA Neurol. -2020. - Vol. 77 (6). P. 683-690.

13. Trejo-Gabriel-Galán J. M. Stroke as a complication and prognostic factor of COVID-19 / J. M. Trejo-GabrielGalán // Neurologia. - 2020. - Vol. 35 (5). - P. 318-322.

14. COVID-19 presenting as stroke / A. Avula, K. Nalleballe, N. Narula [et al.] // Brain Behav. Immun. - 2020. Vol. 87. - P. 115-119.

15. Acute cerebrovascular disease following COVID-19: a single center, retrospective, observational study / Y. Li, M. Li, M. Wang [et al.] // Stroke Vasc. Neurol. - 2020. Vol. 5 (3). - P. 279-284.
16. Zaki N. Association of hypertension, diabetes, stroke, cancer, kidney disease, and high-cholesterol with COVID-19 disease severity and fatality: a systematic review / N. Zaki, H. Alashwal, S. Ibrahim // Diabetes Metab. Syndr. - 2020. - Vol. 14 (5). - P. 1133-1142.

17. Recent bacterial and viral infection is a risk factor for cerebrovascular ischemia: clinical and biochemical studies / A. J. Grau, F. Buggle, H. Becher [et al.] // Neurology. - 1998. - Vol. 50 (1). - P. 196-203.

18. Incidence of thrombotic complications in critically ill ICU patients with COVID-19 / F. A. Klok, M. J. H. A. Kruip, N. J. M. van der Meer [et al.] // Thromb. Res. - 2020. Vol. 191. - P. 145-147.

19. Critically ill COVID-19 infected patients exhibit increased clot waveform analysis parameters consistent with hypercoagulability / C. W. Tan, J. G. H. Low, W. H. Wong [et al.] // Am. J. Hematol. - 2020. - Vol. 95 (7). - P. E156-E158.

20. Acute pulmonary embolism and COVID-19 pneumonia: a random association? / G. B. Danzi, M. Loffi, G. Galeazzi, E. Gherbesi // Eur. Heart J. - 2020. - Vol. 41 (19). - P. 1858.

21. Pulmonary and cardiac pathology in Covid-19: the first autopsy series from new orleans / S. E. Fox, A. Akmatbekov, J. L. Harbert [et al.] // MedRxiv. - 2020. - URL: https:// doi.org/10.1101/2020.04.06.20050575

22. COVID-19 Autopsies, Oklahoma, USA / L. M. Barton, E. J. Duval, E. Stroberg [et al.] // Am. J. Clin. Pathol. 2020. - Vol. 153 (6). - P. 725-733.

23. Yao X. H. A pathological report of three COVID-19 cases by minimal invasive autopsies / X. H. Yao, T. Y. Li, Z. C. He // Zhonghua Bing Li Xue Za Zhi. - 2020. Vol. 49 (5). - P. 411-417.

24. Management of atrial fibrillation in COVID-19 pandemic / Y. F. Hu, W. H. Cheng, Y. Hung [et al.] // Circ. J. 2020. - Vol. 84 (10). - P. 1679-1685.

25. COVID-19 associated atrial fibrillation: Incidence, putative mechanisms and potential clinical implications / M. Gawałko, A. Kapłon-Cieślicka, M. Hohl [et al.] // Int. J. Cardiol. Heart Vasc. - 2020. - Vol. 30. - 100631.

26. COVID-19 and the cardiovascular system: implications for risk assessment, diagnosis, and treatment options / T. J. Guzik, S. A. Mohiddin, A. Dimarco [et al.] // Cardiovasc. Res. - 2020. - Vol. 116 (10). - P. 1666-1687.

27. Stone E. Atrial fibrillation in COVID-19: a review of possible mechanisms / E. Stone, H. Kiat, C. S. McLachlan // FASEB J. - 2020. - Vol. 34 (9). - P. 11347-11354.

28. Characteristics and outcomes of patients hospitalized for COVID-19 and cardiac disease in Northern Italy / R. M. Inciardi, M. Adamo, L. Lupi [et al.] // Eur. Heart J. 2020. - Vol. 41 (19). - P. 1821-1829.

29. Guidance for the management of patients with vascular disease or cardiovascular risk factors and COV- 
Огляди літератури, оригінальні дослідження, погляд на проблему, випадок з практики, короткі повідомлення

ID-19: position paper from VAS-European Independent Foundation in Angiology/Vascular Medicine / G. T. Gerotziafas, M. Catalano, M. P. Colgan [et al.] // Thromb. Haemost. 2020. - Vol. 120 (12). - P. 1597-1628.

30. Dabigatran, the oral anticoagulant of choice at discharge in patients with non-valvular atrial fibrillation and COVID-19 infection: the ANIBAL protocol / T. IturbeHernandez, L. García de Guadiana Romualdo, I. Gil Ortega [et al.] // Drugs Context. - 2020. - Vol. 9. - P. 2020.

31. Rationale and design for the study of rivaroxaban to reduce thrombotic events, hospitalization and death in outpatients with COVID-19: The PREVENT-HD study / W. H. Capell, E. S. Barnathan, G. Piazza [et al.] // Am. Heart J. - 2021. - Vol. 235. - P. 12-23.

32. Sholzberg M. Coagulopathy of hospitalised COVID-19: a pragmatic randomised controlled trial of therapeutic anticoagulation versus standard care as a rapid response to the COVID-19 pandemic (RAPID COVID COAG - RAPID Trial): a structured summary of a study protocol for a randomised controlled trial / M. Sholzberg, G. H. Tang, E. Negri // Trials. 2021. - Vol. 22 (1). - P. 202.

33. Coronavirus Disease 2019 (COVID-19). Treatment Guidelines. - URL: https://www.covid19treatmentguidelines.nih.gov/antithrombotic-therapy.

34. ESC Guidance for the Diagnosis and Management of CV Disease during the COVID-19 Pandemic. - URL: https://www.escardio.org/Education/COVID-19-and-Cardiology/ESC-COVID-19-Guidance

35. Tang D. The hallmarks of COVID-19 disease / D. Tang, P. Comish, R. Kang // PLoS Pathog. - 2020. Vol. 16 (5). - P. 1008536.

36. Kalil A. C. Treating COVID-19-off-label drug use, compassionate use, and randomized clinical trials during pandemics / A. C. Kalil // JAMA. - 2020. - Vol. 323 (19). P. 1897-1898.

37. Naksuk N. Cardiac safety of off-label COVID-19 drug therapy: a review and proposed monitoring protocol / N. Naksuk, S. Lazar, T. B. Peeraphatdit // Eur. Heart J. Acute Cardiovasc Care. - 2020. - Vol. 9 (3). - P. 215-221.

38. Alpern J. D. Off-Label therapies for COVID-19-Are we all in this together? / J. D. Alpern, E. Gertner // Clin. Pharmacol. Ther. - 2020. - Vol. 108 (2). - P. 182-184.

39. Markus H. S. EXPRESS: COVID-19 and Stroke - A Global World Stroke Organisation perspective/H. S. Markus, M. Brainin // Int. J. Stroke. - 2020. - Vol. 15 (14). - P. 361-364.

40. Hospitalization and mortality among black patients and white patients with Covid-19 / E. G. Price-Haywood, J. Burton, D. Fort, L. Seoane // N. Engl. J. Med. 2020. - Vol. 382 (26). - P. 2534-2543.

41. COVID-19 Host Genetics Initiative. The COVID-19 Host Genetics Initiative, a global initiative to elucidate the role of host genetic factors in susceptibility and severity of the SARS-CoV-2 virus pandemic // Eur. J. Hum. Genet. 2020. - Vol. 28 (6). - P. 715-718.

42. Impact of SARS-CoV-2 Pandemic on "Stroke Code" Imaging Utilization and Yield / D. R. Shatzkes, A. B. Zlochower, J. M. Steinklein [et al.] // AJNR Am. J. Neuroradiol. - 2021. DOI: 10.3174/ajnr.A7038

43. Collateral effect of Covid-19 on stroke evaluation in the united states / A. P. Kansagra, M. S. Goyal, S. Hamilton, G. W. Albers // N. Engl. J. Med. - 2020. - Vol. 383 (4). P. 400-401.

44. Impact of COVID-19 on Outcomes in Ischemic Stroke Patients in the United States / A. de Havenon, J. P. Ney, B. Callaghan [et al.] // J. Stroke Cerebrovasc. Dis. 2021. - Vol. 30 (2). - P.105535.

45. Baum A. Admissions to veterans affairs hospitals for emergency conditions during the COVID-19 pandemic / A. Baum, M. D. Schwartz // JAMA. - 2020. - Vol. 324 (1). P. 96-99.

46. Abstract P153: SARS-CoV-2 (COVID-19) protection efforts on acute stroke treatment / J. Greenwood, S. Belnap, R, Bedgio [et al.] // Stroke. - 2021. - Vol. 52. - P.153. URL: https://doi.org/10.1161/str.52.suppl_1.P153

47. Incidence, characteristics and clinical relevance of acute stroke in old patients hospitalized with COVID-19 / A. Mendes, F. R. Herrmann, L. Genton [et al.] // BMC Geriatr. - 2021. - Vol. 21 (1). - P. 52.

48. High incidence of stroke in COVID-19 patients / J. Chen, Y. Wu, Z. Chen [et al.] // Aging (Albany NY). 2020. - Vol. 12 (22). - P. 22390-22398.

49. Increased risk of acute stroke among patients with severe COVID-19: a multicenter study and meta-analysis / T. Siepmann, A. Sedghi, E. Simon [et al.] // Eur. J. Neurol. - 2021. - Vol. 28 (1). - P. 238-247.

50. Impact of the COVID-19 pandemic and national lockdown on hospitalization for stroke and related 30-day mortality in France: a nationwide observational study / A. Gabet, C. Grave, P. Tuppin [et al.] // Neuroepidemiology. - 2021. - Vol. 55 (Suppl. 1). - P. 42.

51. Inbar Zucker Reduction in acute stroke admissions during the COVID-19 pandemic - data from the Israeli national stroke registry / C. Libruder, A. Ram, Y. Hershkovitz [et al.] // Neuroepidemiology. - 2021. - Vol. 55 (Suppl. 1). P. 69.

52. Stroke care during the COVID-19 pandemic: experience from three large European countries / A. Bersano, M. Kraemer, E. Touzé [et al.] // Eur. J. Neurol. - 2020. Vol. 27 (9). - P. 1794-1800.

53. Impact of the COVID-19 Epidemic on Stroke Care and Potential Solutions / J. Zhao, H. Li, D. Kung [et al.] // Stroke. - 2020. - Vol. 51 (7). - P. 1996-2001.

\section{REFERENCES}

1. Li, X., Zai, J., Zhao, Q., Nie, Q., Li, Y., Foley, B.T., \& Chaillon, A. (2020). Evolutionary history, potential intermediate animal host, and cross-species analyses of SARS-CoV-2. J. Med. Virol., 92 (6), 602-611. DOI: 10.1002/ jmv. 25731

2. Wu, A., Peng, Y., Huang, B., Ding, X., Wang, X., Niu, P. \& Jiang, T. (2020). Genome composition and divergence of the novel coronavirus (2019-nCoV) originating in China. Cell Host Microbe, 27 (3), 325-328. DOI: 10.1016/j. chom.2020.02.001 
Огляди літератури, оригінальні дослідження, погляд на проблему, випадок з практики, короткі повідомлення

3. COVID-19 coronavirus pandemic. Retrieved from: https://www.worldometers.info/coronavirus

4. Tsai, L.K., Hsieh, S.T., \& Chang, Y.C. (2005). Neurological manifestations in severe acute respiratory syndrome. Acta Neurol. Taiwan, 14, 113-119.

5. Moriguchi, T., Harii, N., Goto, J., Harada, D., Sugawara, H., Takamino, J., \& Shimada, S. (2020). A first case of meningitis/encephalitis associated with SARS-Coronavirus-2. Int. J. Infect. Dis., 94, 55-58. DOI: 10.1016/j. ijid.2020.03.062

6. Wu, Y., Xu, X., Chen, Z., Duan, J., Hashimoto, K., Yang, L., \& Yang, C. (2020). Nervous system involvement after infection with COVID-19 and other coronaviruses. Brain Behav. Immun., 87, 18-22. DOI: 10.1016/j.bbi.2020.03.031

7. Hess, D.C., Eldahshan, W., \& Rutkowski, E. (2020). COVID-19-Related Stroke. Transl. Stroke Res., 11 (3), 322325. DOI: 10.1007/s12975-020-00818-9

8. Hoffmann, M., Kleine-Weber, H., Schroeder, S., Krüger, N., Herrler, T., Erichsen, S., \& Pöhlmann, S. (2020). SARS-CoV-2 cell entry depends on ACE2 and TMPRSS2 and is blocked by a clinically proven protease inhibitor. Cell, 181 (2), 271-280. DOI: 10.1016/j.cell.2020.02.052

9. Steardo, L., Steardo, L. Jr, Zorec, R., \& Verkhratsky, A. (2020). Neuroinfection may contribute to pathophysiology and clinical manifestations of COVID-19. Acta Physiol (Oxf), 229 (3), e13473. DOI: 10.1111/apha.13473

10. Huang, C., Wang, Y., Li, X., Ren, L., Zhao, J., Hu, Y., \& Cao, B. (2020). Clinical features of patients infected with 2019 novel coronavirus in Wuhan, China. Lancet, 395 (10223), 497-506. DOI: 10.1016/S0140-6736(20)30183-5

11. Inciardi, R.M., Lupi, L., Zaccone, G., Italia, L., Raffo, M., Tomasoni, D., \& Metra, M. (2020). Cardiac involvement in a patient with coronavirus disease 2019 (COVID-19). JAMA Cardiol., 5 (7), 819-824. DOI: 10.1001/jamacardio.2020.1096

12. Mao, L., Jin, H., Wang, M., Hu, Y., Chen, S., He, Q., \& Hu, B. (2020). Neurologic manifestations of hospitalized patients with coronavirus disease 2019 in Wuhan, China. JAMA Neurol., 77 (6), 683-690. DOI: 10.1001/jamaneurol.2020.1127

13. Trejo-Gabriel-Galán, J.M. (2020). Stroke as a complication and prognostic factor of COVID-19. Neurologia, 35 (5), 318-322. DOI: 10.1016/j.nrl.2020.04.015

14. Avula, A., Nalleballe, K., Narula, N., Sapozhnikov, S., Dandu, V., Toom, S., \& Elsayegh, D. (2020). COVID-19 presenting as stroke. Brain Behav. Immun., 87, 115-119. DOI: 10.1016/j.bbi.2020.04.077

15. Li, Y., Li, M., Wang, M., Zhou, Y., Chang, J., Xian, Y., \& Hu, B. (2020). Acute cerebrovascular disease following COVID-19: a single center, retrospective, observational study. Stroke Vasc. Neurol., 5 (3), 279-284. DOI: 10.1136/ svn-2020-000431

16 Zaki, N., Alashwal, H., \& Ibrahim, S. (2020). Association of hypertension, diabetes, stroke, cancer, kidney disease, and high-cholesterol with COVID-19 disease severity and fatality: A systematic review. Diabetes Metab. Syndr., 14 (5), 1133-1142. DOI: 10.1016/j.dsx.2020.07.005

17. Grau, A.J., Buggle, F., Becher, H., Zimmermann, E., Spiel, M., Fent, T., \& Hacke, W. (1998). Recent bacterial and viral infection is a risk factor for cerebrovascular ischemia: clinical and biochemical studies. Neurology, 50 (1), 196-203. DOI: $10.1212 /$ wnl.50.1.196
18. Klok, F.A., Kruip, M.J.H.A., van der Meer, N.J.M., Arbous, M.S., Gommers, D.A.M.P.J., Kant, K.M., \& Endeman, H. (2020). Incidence of thrombotic complications in critically ill ICU patients with COVID-19. Thromb, Res., 191, 145-147. DOI: 10.1016/j.thromres.2020.04.013

19. Tan, C.W., Low, J.G.H., Wong, W.H., Chua, Y.Y., Goh, S.L., \& Ng, H.J. (2020). Critically ill COVID-19 infected patients exhibit increased clot waveform analysis parameters consistent with hypercoagulability. Am. J. Hematol., 95 (7), E156-E158. DOI: 10.1002/ajh.25822

20. Danzi, G.B., Loffi, M., Galeazzi, G., \& Gherbesi, E. (2020). Acute pulmonary embolism and COVID-19 pneumonia: a random association? Eur. Heart J., 41 (19), 1858. DOI: 10.1093/eurheartj/ehaa254

21. Fox, S.E., Akmatbekov, A., Harbert, J.L., Li, G., Brown, J.Q., \& Vander Heide, R.S. (2020). Pulmonary and cardiac pathology in Covid-19: the first autopsy series from new orleans. medRxiv. Retrieved from: https://doi. org/10.1101/2020.04.06.20050575

22. Barton, L.M., Duval, E.J., Stroberg, E., Ghosh, S., \& Mukhopadhyay, S. (2020). COVID-19 Autopsies, Oklahoma, USA. Am. J. Clin. Pathol., 153 (6), 725-733. DOI: 10.1093/ ajcp/aqaa062

23. Yao, X.H., Li, T.Y., He, Z.C., Ping, Y.F., Liu, H.W., Yu, S.C., \& Bian, X.W. (2020). A pathological report of three COVID-19 cases by minimal invasive autopsies. Zhonghua Bing Li Xue Za Zhi, 49 (5), 411-417. DOI: 10.3760/ cma.j.cn112151-20200312-00193

24. Hu, Y.F., Cheng, W.H., Hung, Y., Lin, W.Y., Chao, T.F., Liao, J.N., \& Chen, S.A. (2020). Management of atrial fibrillation in COVID-19 pandemic. Circ. J., 84 (10), 1679-1685. DOI: 10.1253/circj.CJ-20-0566

25. Gawałko, M., Kapłon-Cieślicka, A., Hohl, M., Dobrev, D., \& Linz, D. (2020). COVID-19 associated atrial fibrillation: Incidence, putative mechanisms and potential clinical implications. Int. J. Cardiol. Heart Vasc., 30, 100631. DOI: 10.1016/j.ijcha.2020.100631

26. Guzik, T.J., Mohiddin, S.A., Dimarco, A., Patel, V., Savvatis, K., Marelli-Berg, F.M., \& Mclnnes, I.B. (2020). COVID-19 and the cardiovascular system: implications for risk assessment, diagnosis, and treatment options. Cardiovasc. Res., 116 (10), 1666-1687. DOI: 10.1093/cvr/cvaa106

27. Stone, E., Kiat, H., \& McLachlan, C.S. (2020). Atrial fibrillation in COVID-19: a review of possible mechanisms. FASEB J., 34 (9), 11347-11354. DOI: 10.1096/fj.202001613.

28. Inciardi, R.M., Adamo, M., Lupi, L., Cani, D.S., Di Pasquale, M., Tomasoni, D., \& Metra, M. (2020). Characteristics and outcomes of patients hospitalized for COVID-19 and cardiac disease in Northern Italy. Eur. Heart J., 41 (19), 1821-1829. DOI: 10.1093/eurheartj/ehaa388

29. Gerotziafas, G.T., Catalano, M., Colgan, M.P., Pecsvarady, Z., Wautrecht, J.C., Fazeli, B., \& Zhai, Z. (2020). Guidance for the management of patients with vascular disease or cardiovascular risk factors and COVID-19: position paper from VAS-European Independent Foundation in Angiology/Vascular Medicine. Thromb. Haemost., 120 (12), 1597-1628. DOI: 10.1055/s-0040-1715798

30. Iturbe-Hernandez, T., García de Guadiana Romualdo, L., Gil Ortega, I., Martínez Francés, A., Meca Birlanga, O., \& Cerezo-Manchado, J.J. (2020). Dabigatran, the oral anticoagulant of choice at discharge in patients with non-valvular atrial fibrillation and COVID-19 infection: the ANIBAL 
Огляди літератури, оригінальні дослідження, погляд на проблему, випадок з практики, короткі повідомлення

protocol. Drugs Context, 9, 2020-8-3. DOI: 10.7573/ dic.2020-8-3

31. Capell, W.H., Barnathan, E.S., Piazza, G., Spyropoulos, A.C., Hsia, J., Bull, S., \& Bonaca, M.P. (2021). Rationale and design for the study of rivaroxaban to reduce thrombotic events, hospitalization and death in outpatients with COVID-19: the PREVENT-HD study. Am. Heart J., 235, 12-23. DOI: 10.1016/j.ahj.2021.02.001

32. Sholzberg, M., Tang, G.H., Negri, E., Rahhal, H., Kreuziger, L.B., Pompilio, C.E., \& Jüni, P. (2021). Coagulopathy of hospitalised COVID-19: a Pragmatic randomised controlled trial of therapeutic anticoagulation versus standard care as a rapid response to the COVID-19 pandemic (RAPID COVID COAG - RAPID Trial): a structured summary of a study protocol for a randomised controlled trial. Trials, 22 (1), 202. DOI: 10.1186/s13063-021-05076-0

33. Coronavirus disease 2019 (COVID-19). Treatment guidelines. Retrieved from: https://www.covid19treatmentguidelines.nih.gov/antithrombotic-therapy

34. ESC Guidance for the Diagnosis and Management of CV Disease during the COVID-19 Pandemic. Retrieved from: https://www.escardio.org/Education/COVID-19-andCardiology/ESC-COVID-19-Guidance

35. Tang, D., Comish, P., \& Kang, R. (2020). The hallmarks of COVID-19 disease. PLoS Pathog., 16(5), e1008536. DOI: 10.1371/journal.ppat.1008536

36. Kalil, A.C. (2020). Treating COVID-19-off-label drug use, compassionate use, and randomized clinical trials during pandemics. JAMA, 323 (19), 1897-1898. DOI: $10.1001 /$ jama.2020.4742

37. Naksuk, N., Lazar, S., \& Peeraphatdit, T.B. (2020). Cardiac safety of off-label COVID-19 drug therapy: a review and proposed monitoring protocol. Eur. Heart J. Acute Cardiovasc. Care, 9 (3), 215-221. DOI: 10.1177/2048872620922784

38. Alpern, J.D., \& Gertner, E. (2020). Off-label therapies for COVID-19-are we all in this together? Clin. Pharmacol. Ther., 108 (2), 182-184. DOI: 10.1002/cpt.1862

39. Markus, H.S. (2020). EXPRESS: COVID-19 and Stroke - A Global World Stroke Organisation perspective. Int. J. Stroke, 15 (4), 361-364. DOI: $10.1177 / 1747493020923472$

40. Price-Haywood, E.G., Burton, J., Fort, D., \& Seoane, L. (2020). Hospitalization and mortality among black patients and white patients with Covid-19. N. Engl. J. Med., 382 (26), 2534-2543. DOI: 10.1056/NEJMsa2011686

41. COVID-19 Host Genetics Initiative. (2020). The COVID-19 Host Genetics Initiative, a global initiative to elucidate the role of host genetic factors in susceptibility and severity of the SARS-CoV-2 virus pandemic. Eur. J. Hum. Genet., 28 (6), 715-718. DOI: 10.1038/s41431-020-0636-6

42. Shatzkes, D.R., Zlochower, A.B., Steinklein, J.M., Pramanik, B.K., Filippi, C.G., Azhar, S., \& Sanelli, P.C. (2021). Impact of SARS-CoV-2 pandemic on "Stroke Code" imaging utilization and yield. AJNR Am. J. Neuroradiol. DOI: 10.3174/ajnr.A7038

43. Kansagra, A.P., Goyal, M.S., Hamilton, S., \& Albers, G.W. (2020). Collateral effect of Covid-19 on Stroke Evaluation in the United States. N. Engl. J. Med., 383 (4), 400-401. DOI: 10.1056/NEJMc2014816

44. de Havenon, A., Ney, J.P., Callaghan, B., Delic, A., Hohmann, S., Shippey, E., \& Majersik, J.J. (2021). Impact of COVID-19 on outcomes in ischemic stroke patients in the United States. J. Stroke Cerebrovasc. Dis., 30 (2), 105535. DOI: 10.1016/j.jstrokecerebrovasdis.2020.105535

45. Baum, A., \& Schwartz, M.D. (2020). Admissions to veterans affairs hospitals for emergency conditions during the COVID-19 pandemic. JAMA, 324 (1), 96-99. DOI: 10.1001/jama.2020.9972.

46. Greenwood, J., Belnap, S., Bedgio, R, Dabus, G., Linfante, I., \& De Los Rios La Rosa, F. (2021). Abstract P153: SARS-CoV-2 (COVID-19) protection efforts on acute stroke treatment. Stroke, 52, 153. DOI: https://doi.org/10.1161/ str.52.suppl_1.P153

47. Mendes, A., Herrmann, F.R., Genton, L., Serratrice, C., Carrera, E., Vargas, M.I., \& Scheffler, M. (2021). Incidence, characteristics and clinical relevance of acute stroke in old patients hospitalized with COVID-19. BMC Geriatr., 21 (1), 52. DOI: 10.1186/s12877-021-02006-2

48. Chen, J., Wu, Y., Chen, Z., Yi, B., Zhang, L., Yin, C., \& Feng, H. (2020). High incidence of stroke in COVID-19 patients. Aging (Albany NY), 12 (22), 22390-22398. DOI: 10.18632 /aging.104092

49. Siepmann, T., Sedghi, A., Simon, E., Winzer, S., Barlinn, J., de With, K., \& Barlinn, K. (2021). Increased risk of acute stroke among patients with severe COVID-19: a multicenter study and meta-analysis. Eur. J. Neurol., 28 (1), 238-247. DOI: 10.1111/ene.14535

50. Gabet, A., Grave, C., Tuppin, P., Béjot, Y., \& Olié, V. (2021). Impact of the COVID-19 pandemic and national lockdown on hospitalization for stroke and related 30-day mortality in France: a nationwide observational study. Neuroepidemiology, 55 (1), 42. DOI: 10.1111/ene.14831

51. Libruder, C., Ram, A., Hershkovitz, Y., Tanne, D., Bornstein, N., Leker, R., \& Zucker, I. (2021). Reduction in acute stroke admissions during the COVID-19 pandemic data from the Israeli national stroke registry. Neuroepidemiology, 55 (1), 69.

52. Bersano, A., Kraemer, M., Touzé, E., Weber, R., Alamowitch, S., Sibon, I., \& Pantoni, L. (2020). Stroke care during the COVID-19 pandemic: experience from three large European countries. Eur. J. Neurol., 27 (9), 1794-1800. DOI: 10.1111/ene.14375

53. Zhao, J., Li, H., Kung, D., Fisher, M., Shen, Y., \& Liu, R. (2020). Impact of the COVID-19 epidemic on stroke care and potential solutions. Stroke, 51 (7), 1996-2001. DOI: 10.1161/STROKEAHA.120.030225 
Огляди літератури, оригінальні дослідження, погляд на проблему, випадок з практики, короткі повідомлення

\title{
ОСТРЫЕ НАРУШЕНИЯ МОЗГОВОГО КРОВООБРАЩЕНИЯ У БОЛЬНЫХ COVID-19
}

\section{๑Т. М. Муратова', Д. М. Храмцов ${ }^{1,3}$, Ю. М. Ворохта ${ }^{2,3}$, М. С. Викаренко ${ }^{1,3}$, И. В. Добуш ${ }^{1,3}$,} Г. Г. Козлова', 3 , Е. О. Андрющенко ${ }^{3}$ В. М. Сазонов³, В. А. Фащенко

${ }^{1}$ Одесский национальный медицинский университет

годесский международный медицинский университет

зЧастный медицинский чентр «Ехрегt Health», г. Одесса

РЕЗЮМЕ. В декабре 2019 года из города Ухань (провинция Хубэй, Китай) поступили первые сообщения о COVID-19 - заболевании, вызванном новым тяжелым острым респираторным синдромом коронавирусной этиологии (SARS-CoV-2). С того времени эта болезнь стала мировой пандемией. На сегодняшний день погибло более 2,8 миллиона человек (BO3, 2021). Вирус SARS-CoV-2 стал седьмым известным вариантом коронавируса, патогенным для человека.

Целью обзора была оценка влияния инфекции SARS-CoV-2 на распространенность ОНМК в странах мира.

Материал и методы. Ретроспективное исследование проведено по материалам международных баз данных (CDC, BO3), а также реестров OHMK (SITS, resQ, DAP, GSR, SSR, LASE). Проведено сопоставление инкремента заболеваемости SARS-CoV-2 и OHMK в динамике с момента выявления первых случаев COVID-19. Статистическая обработка проводилась с помощью программного обеспечения Statistica 13.0 (TIBCO Inc., CШA).

Результаты. Частота ОНMК в мире коррелирует с распространенностью SARS-CoV-2. На ранних стадиях пандемии COVID-19 в развитых странах происходило уменьшение заболеваемости ОНМК. Существующие международные реестры ОНМК отражают сохранение этой тенденции.

Выводы. 1. Пандемия COVID-19 связана с глобальным уменьшением обращения за специализированной медицинской помощью при ОНМК, что влияет на общее количество госпитализаций и числа процедур механической тромбэктомии.

2. Несмотря на географические различия, это уменьшение объема наблюдалось независимо от бремени госпитализации COVID-19 и объемов госпитализации больных с ОНМК в допандемический период.

КЛЮЧЕВЫЕ СЛОВА: острое нарушение мозгового кровообращения; коронавирусная инфекция; эпидемиология.

\section{ACUTE DISORDERS OF CEREBRAL CIRCULATION IN PATIENTS WITH COVID-19}

\author{
๑)T. M. Muratova1, D. M. Khramtsov ${ }^{1,3}$, Yu. M. Vorokhta ${ }^{2,3}$, M. S. Vikarenko ${ }^{1,3}$, I. V. Dobush ${ }^{1,3}$, \\ G. G. Kozlova ${ }^{1,3}$, Ye. O. Andryushchenko³, V. M. Sazonov³, V. A. Fashchenko ${ }^{3}$ \\ ${ }^{1}$ Odesa National Medical University, \\ 2Odesa International Medical University, \\ ${ }^{3}$ Private medical center "Expert Health", Odesa
}

SUMMARY. In December 2019, the first reports of COVID-19, a disease caused by a new severe acute respiratory syndrome of coronaviral etiology (SARS-CoV-2), were received from Wuhan (Hubei Province, China). Since then, the disease has become a global pandemic. To date, more than 2.8 million people have died (WHO, 2021). SARS-CoV-2 virus became the seventh known variant of coronavirus pathogenic to humans.

The aim - to assess the impact of SARS-CoV-2 infection on the prevalence of stroke in the countries of the world.

Material and Methods. The retrospective study was carried out using materials from international databases (CDC, WHO), as well as CVA registries (SITS, resQ, DAP, GSR, SSR, LASE). Comparison of the incidence rate of SARS-CoV-2 and CVA over time since the detection of the first cases of COVID-19. Statistical processing was performed using Statistica 13.0 software (TIBCO Inc., USA).

Results. The stroke occurrence in the world correlates with the prevalence of SARS-CoV-2. In the early stages of the COVID-19 pandemic, there was a decrease in the incidence of stroke in developed countries. The existing international stroke registries reflect the persistence of this trend.

Conclusions. 1. The COVID-19 pandemic is associated with a global decrease in the use of specialized medical care for stroke, which affects the total number of hospitalizations and the number of mechanical thrombectomy procedures.

2. Despite geographical differences, this decrease in volume was observed regardless of the burden of COVID-19 hospitalization of and the patients with stroke in the pre-pandemic period.

KEY WORDS: acute cerebrovascular accident; coronavirus infection; epidemiology. 